\title{
Pre-service Physical Education Teachers'self-management ability: a training experience in 3D simulation environments \\ La competencia de autogestión de los futuros maestros de Educación Física: una experiencia formativa en entornos de simulación 3D \\ Luis Marqués Molías, Jose Cela Ranilla, Mercè Gisbert Cervera Universidad Rovira i Virgili (España)
}

\begin{abstract}
This study analyses the differences between pre-service Physical Education Teachers (PET) and other students of Education with regard to the ability of self-management. The sample comprised of 58 Spanish students of Education in their last year at the university. The comparison context was a 3D simulation learning environment. Descriptive statistics and non-parametric tests were conducted to develop this research work. Results showed that this technological environment is a space in which students of Education display a high level of self-management ability performance. Results also evince that PET students present better scores than other students of Education in terms of self-management.

Keywords. Higher Education, Physical Education, Physical Education Teachers, Simulation, 3D worlds, Project-based learning, Self-management.
\end{abstract}

Resumen. Este estudio analiza las diferencias entre estudiantes para maestros de Educación Primaria con la especialidad de Educación Física y otros estudiantes de Educación respecto a la competencia de autogestión. En este estudio participaron 58 estudiantes españoles de Educación en su último año de universidad. El contexto en el que se desarrolló la experiencia fue un entorno de aprendizaje de simulación 3D. Para su análisis se realizaron estadísticos descriptivos y pruebas no paramétricas. Los resultados mostraron que este entorno tecnológico es un espacio en el cual los estudiantes de Educación despliegan un alto nivel de desempeño en la competencia de autogestión. Los resultados también ponen de manifiesto que los estudiantes de Educación Física obtienen mejores resultados que estudiantes de otras disciplinas respecto a la competencia de autogestión.

Palabras clave. Educación Superior, Educación Física, Maestros de Educación Física, Simulación, Mundos 3D, Aprendizaje basado en Proyectos, Autogestión.

\section{Introduction}

The educational model suggested in the European convergence has been mainly characterized by the centered position of the student. To put the student in a central part requires knowledge of his/her academic and professional profile in order to design adequate learning activities. The definition of the new curricula based on competences is an important structural component of the European convergence process.

In the Spanish context, some studies faced deep structural transformations; concretely, the traditional Teaching Education curricula has been transformed in terms of contents and the number of credits based on specific skills. Current educational plans has become in two different ones: InfantEducation and Primary Education. This conjuncture is a propitious moment for designing some specific programs in a very accurate manner oriented toward a specific concretion.

Concretely, the profile of students who want to become Teachers of Physical Education (hereafter PET) needs to be the object of special attention (Tozer \& Horsley, 2006). This collective tends to be considered in a differentiated manner, not only in their professional competences but also in terms of status or social consideration (Hoyle, 2001). Several educative collectives share a common idea: students who are studying to become PET show a different profile regarding other teaching branches in developing their performance both as learners and professionals.

In parallel, the competences attributed to PET students and PE professionals are linked to an action component. This collective must put theory into practice in a more explicit manner than other teaching practitioners. This feature fits with the essence of a new curricular model that is defined in terms of competences. PET students give greater value to those skills that can be transferred to professional practices, teamwork, self-management and/or planning and organization (Romero et al., 2011).

Students who are studying a bachelor's degree to become PET show a specific profile that makes them different regarding other teaching specialties in developing their performance both as learners and professionals. In otherwords, teachers' profile requires managing projects and training activity that imply actions and application of knowledge.

Once analyzed the specific PET professionals' profile and curricula

Fecha recepción: 03-03-16. Fecha de aceptación: 04-11-16

Luis Marqués Molías

luis.marques@urv.cat
(ANECA, 2005), we detected that competences oriented toward acting and managing projects are relevant for them. Our study is precisely focused on the skill of «self-management; this term can be understood in a polysemic sense; in fact, self-management arises as a term linked to scientific disciplines such as health, business and education. In this work, management is used as personal management.

To clarify our point on this matter, we analyze self-management as a transversal skill that must be acquired to perform both academically and professionally. We observe self-management in terms of the planning of activities to construct an artefact with a constant regulatory system.

Additionally, basic skills in technology environments are essential for students to act effectively in the academic and labour settings, as well as in everyday activities (Ezziane, 2007). The current technology offers new and rich opportunities for training that implies action; concretely, simulation constitutes an environment for developing learning actions that imply challenges, competition, cooperation and authentic tasks (Chang, Peng \& Chao, 2010; Girvan \& Savage, 2010); these principles are essential parts of the habitual tasks of PET.

In sum, this research work integrates the following elements: preservices PET students, self-management as skill to be developed and 3D simulation as learning environment.

The general aim of this paper revolves around the differential fact of PET students with regard to the self-management skill compared to other educational students' profiles. We search for these differences by observing how they perform in a 3D learning environment. Developing this aim two questions can be formulated: do PET students act differently from other education students when they use the self-management skill during a project's development? And, is a 3D simulation a good learning environment to search for these differences?

\section{PET students}

The existence of PET as a profession is mainly based on their expert contribution to transmitting values and knowledge accepted as positive in our society. The label of these professionals is justified insofar as they represent aspects oriented toward individual development, in contrast with the values that can be transmitted by other figures such as coaches, who are more oriented to the improvement of sporting performance (Hind \& Palmer, 2007).

The mission of PETs contains nuclear elements that take part in everyday life. Promoting and communicating good health and wellbeing are transversal features that justify the existence of the $\mathrm{PE}$ 
professionals.

Despite that some recent changes occurred, PETs have been historically observed in a differentiated manner, not only in their professional competences but also in terms of identity, status or social consideration (Hendry, 1975). In this sense, an adequate evolution is shown at observing that current PET are more oriented toward the educational aspects rather than sport performance(O’Bryant, O’Sullivan \& Raudensky, 2000).

Deepening on the professionalization concept, there are research works in which PETs' working conditions are rather under-represented and jeopardize PE teachers' power in curriculum dissemination processes (Hoyle, 2001; Kougioumtzis, Patriksson \& Stråhlman, 2011). Therefore, we must be aware that this workplace configuration starts to be built at the very beginning, since the pre-service PET classrooms to University. Brouwers, Tomic \& Boluijt (2011) states that «in comparison with teachers of other subjects, some striking differences are the skills that students have to be taught and the way lessons are organized».

Recent works relate beliefs about teaching and teachers' identity; in fact, these beliefs, independently of their truthfulness, shape the Physical Education (hereafter PE) workplace (Barker \& Rossi, 2011). Some current research works talk about PE and PET in terms of description (Hodges-Kulinna et al., 2010; Ward \& Ko, 2006); however, as Tozer \& Horsley (2006) state «efforts to review research on in-service PE teachers and their working conditions are rather rare».

Following the argument, a more extended work would be necessary concerning PETs reality; in this sense, analyzing pre-service PET could facilitate relevant and objective information in order to improve both $\mathrm{PE}$ and PET perceptions from the scholar and social community.

\section{Self-management}

The design of new curricula in European Higher Education Area (hereafter EHEA) is made up in terms of competences and learning outcomes. Anuclear part of these plans contains transversal competences, that is to say, those that must be developed whatever the context of application. Concretely, generic or transversal skills are understood as competences that are common to the majority of professions, contribute to valued outcomes for societies and individuals, and help individuals meet important demands in a wide range of contexts (OECD, 2005).

The skill of self-management has been defined in diverse terms; following we present three different ways to be observed: one is selfdirection or the ability to set goals for learning, plan for the achievement of those goals, independently manage time and effort, and independently assess the quality of learning and any products resulting from the learning experience (Burkhardt et al., 2003); secondly as project management understood as the application of knowledge, skills, tools and techniques to the project activities in order to achieve the fixed objectives (OECD, 2005); and thirdly (Partnership for 21st Century Skills, 2011) as a set of goals with tangible and intangible success criteria: balancing tactical and strategic goals; utilizing time and managing workload efficiently; and monitoring, defining, prioritizing and completing tasks without direct oversight.

In the current research, self-management is understood as acting strategically on a project, process or activity in order to anticipate which actions to take and make the right decisions during its development. In other words, project management means applying knowledge, skills, tools and techniques to the project activities in order to achieve the fixed objectives. To add an action component, we observe self-management in terms of the planning of activities to construct an artefact with a constant regulatory system.

Whatever the skills, their definitions need to be operationalized in order to work and assess them according to their complexity (Simpson, 2003; Prades, 2005). This skill is described through four dimensions of an analytical rubric developed in a Spanish research and development project called Simul@ (2012): Planning (to anticipate actions for developing a systematic and efficient working process coherent with the defined aims); Organization (to develop a temporal sequence for tasks, assign responsibilities, and anticipate the resources needed when planning); Development (to implement and readjust the defined process); and Assessment (to identify, obtain and analyze information to guide decision making during the process, solve problems, and suggest improvements).

\section{D learning environment of simulation}

Digital technologies in the digital era presents situations that require individuals to employ a growing assortment of cognitive skills in order to perform and solve problems in new environments (Aviram \& EshetAlkalai, 2006).

Using simulations in technological environments allows students to access data and information from remote sites, to relate visible and invisible data, to manipulate environments and variables, to influence changes or processes and to practice skills that would be difficult to develop in real life. Experimentation with these spaces and tools for simulation could facilitate the students' acquisition of competences and construction of knowledge.

Technologic environments have great potential in education for training, experimentation and evaluation (Alrayes \& Sutcliffe, 2011; Allen \& Demchak, 2011) and can constitute an extraordinary didactic scenario in which students can act collaboratively (Gisbert, Cela-Ranilla \& Isus, 2010).

Exploration of new learning environments such as simulation implicitly provides us with the opportunity to evaluate contents beyond traditional knowledge; a 3D environment enables assessment in terms of competences or skills. Nowadays, different serious games and virtual worlds (e.g. River City, Quest Atlantis, Second live, Sloodle) have been used to assess students using the embedded assessment and/or specific evaluation engines (Morillo et al. 2010). This way of evaluation allows users to be continuously informed about their learning process by means of a range of integrated tools as well as modify their actions while the process is occurring.

\section{Method}

A training activity was proposed to be developed by Education students (PET students and non-PET students). A non-experimental ex-post method was conducted in order to compare both groups: PET and non-PET students.

Both process and product, as dependent variables, were analyzed in a differentiated manner.

Regarding the process, an experts' group registered (by nonparticipant observation) the activity of the students by using an analytical rubric as reference. The statistical analysis conducted, once the nonnormality distribution of the sample was verified, consisted of descriptive statistics estimation and a non-parametric Independent samples Man-Whitney U test. This non-parametric test is appropriate for comparing non-normally distributed samples independently of their size and shape (Leech \& Onwuegbuzie, 2002). Although authors such as Green \& Salkind (2008) or Field (2005) state that a simple estimation of the differences between mean ranks of groups could be informative enough, the effect size was calculated $(r=Z / S Q R T N)$ in order to go deeper into the comparison between groups (Fritz, Morris, \& Richler, 2011).

Six experts assessed the final product generated by each group of students. The mean value and the standard deviation was used to estimate and validate the experts' evaluation.

\section{Experimental context: Participants, learning context and didactic} proposal

\section{Participants}

Participants involved 58 Education students (74.1\% female and $25.9 \%$ male) with a mean age of 23.34 (sd= 5.18) belonging to the following studies: Teacher Training: Infant Education and Primary Education (81\%) and Teacher Training: Physical Education (19\%). Describing each group to be compared, PET students contain 27,3\% 
female and 72,7 male with a mean age of 23,65 (sd= 5,66); Non-PET students contain $85,1 \%$ female and $14,9 \%$ male with a mean age of 22,09 (sd=2,27).

\section{Learning context}

The specific training activity to be developed by students took place in a 3D learning environment of simulation; concretely in the multi-user virtual environment of Opensim; this environment was integrated with the learning-management system Moodle by means of a specific module named Sloodle that enables the link between objects in the virtual world and tasks in Moodle (see Figure 1).

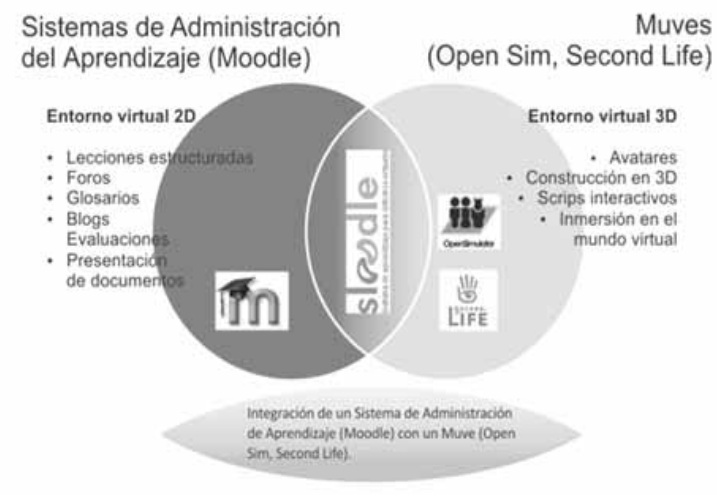

Figure 1: Technologic infrastructure (Samaniego et al., 2011)

\section{The didactic proposal}

The teaching activity was integrated as a normal learning activity in the academic course of the Bachelor of Teacher Training. Teachers designed a didactic proposal following a project-based learning structure; the proposal was the same for both groups in terms of structure; that is, the only difference was the content to work with in dependence on the disciplinary specification. The PET students had to organize, design and present a «Scholar Olympic Games» and non-PET students had to do the same process to present a «School Center». This didactic framework allowed us to compare groups in terms of the cognitive processes to be developed.

The whole activity lasted four weeks with no restrictions on access to the virtual world. The didactic sequence consisted of four phases: preliminary, planning, development/construction and reporting (CelaRanilla et al., 2011)

The preliminary phase contains actions related to the introduction of students to the OpenSim environment, project explanation and gathering of student diagnostic information. This phase concludes with the formation of the working groups.

-The planning phase is when the students develop specific activities to accumulate points that can be exchanged for resources at the end of this phase. The activities are related to the specific content and are of a
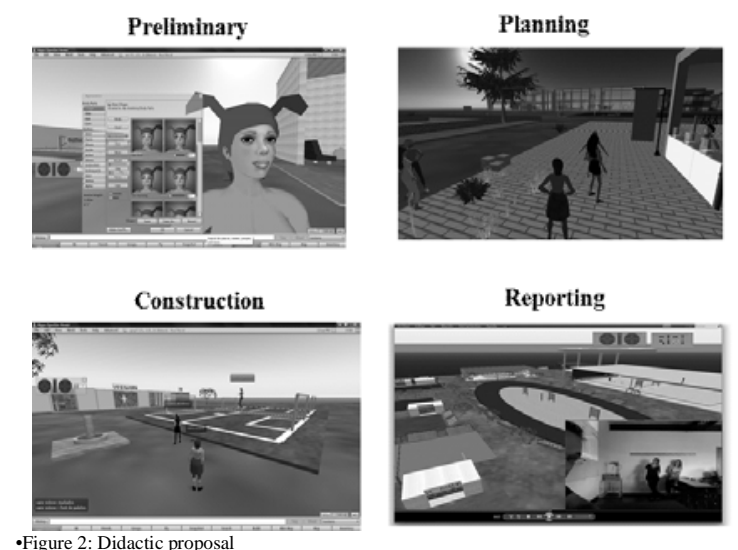

diverse nature: organization (personal, spaces, documents), elaboration (lists, budgets, calendar), anticipation and explanation / justification.

-Development/construction is the phase in which each working group builds its project by creating its own resources as well as using and managing the resources earned in the prior activities.

- The reporting phase consists of the moment in which each group presents and defends its project in front of an experts' committee.

\section{Procedure, Instruments and Assessmentprocess}

\section{Procedure}

The whole activity took place over 1 month in the second semester of the 2010-11 academic year. The students were informed about their participation in a research experience and they were asked about their agreement to participate.

\section{The instruments}

Two instruments were used to analyze the self-management in terms of process and product (see table 1).

Regarding the process, this was assessed at different levels of aggregation (dimensions and elements/indicators) that define the whole concept in an analytical manner (see table 1). The dimensions (Planning, Organization, Development and Assessment) were assessed by using an analytical rubric whose content was validated in mentioned Simul@ project. The rubric is organized with different levels of aggregation that go from abstract dimensions to specific and concrete elements that are measured on a 1-4 scale. The indicators that refer to the assessed dimensions are expressed in Table 1 . These elements were assessed by an expert by means of participant observation using an indicators system based on a 1-4 scale (later on, this scale is recalculated to 1-10). Here are some examples: «1.1 Motivation»: (1) he/she does not show interest in the activity/project; (2) Occasionally, he/she shows interest in the activity/ project; (3) he/she always shows interest in the activity/project; (4) he/ she assumes the activity/project as their own. «2.2 Assignment of responsibilities»: (1) he/she does not assign responsibilities; (2) he/she assigns responsibilities with no adequate criteria; (3) he/she assigns responsibilities with adequate and hierarchical criteria; (4) he/she assigns responsibilities with adequate and hierarchical criteria and proposes alternative options oriented to improvement. «3.2 Monitoring»: (1) he/ she does not adapt the established plan; (2) he/she develops some adaptation actions; (3) he/she develops the needed adaptation actions; (4) he/she develops the adaptation actions and improves the planned project. «4.2 Improvement orientation»: (1) he/she does not make improvement proposals; (2) he/she makes some improvement proposals; (3) he/she makes adequate and feasible improvement proposals; (4) he/she develops a new plan based on the proposed actions.

The product, named as «The Island», was assessed by 6 experts by measuring the 3 following criteria: Organization, Variety of objects and Relevance. The experts (2 teachers, 1 researcher, 1 design expert and 2 master students) assessed the islands developed by each group of

\begin{tabular}{|c|c|c|c|c|}
\hline & Assessment $\mathrm{Cl}$ & eria (Dimensions/elements) & Instrument & Evaluators \\
\hline Process & $\begin{array}{l}\text { Self- } \\
\text { management }\end{array}$ & $\begin{array}{l}\text { 1.Planning } \\
\text { 1.Motivation } \\
\text { 2.Analysis of proposal } \\
\text { 3.Formulation of objectives } \\
\text { 4.Tasks planning } \\
\text { 2. Organization } \\
\text { 1.Time management } \\
\text { 2.Assignment of responsibilities } \\
\text { 3.Assumption of responsibilities } \\
\text { 4.Estimation of resources } \\
\text { 5.Location/selection of resources } \\
\text { 3.Development } \\
\text { 1.Actions } \\
\text { 2.Monitoring } \\
\text { 4.Assessment } \\
\text { 1.Assessment criteria } \\
\text { 2.Improvement orientation }\end{array}$ & $\begin{array}{l}\text { Analytical } \\
\text { rubric (scale } \\
1-4 \\
\text { recalculated } \\
\text { to } 1-10 \text { ) }\end{array}$ & $\begin{array}{l}\text { Participant } \\
\text { observer }\end{array}$ \\
\hline Product & The island & $\begin{array}{l}\text {-Organization } \\
\text {-Variety of objects } \\
\text {-Relevance }\end{array}$ & $\begin{array}{l}\text { Judgement } \\
\text { of experts }\end{array}$ & 6 Experts \\
\hline
\end{tabular}


students; therefore, the final score corresponds to a group performance. Each of them was measured by using a specific tool. This instrument consists of a 1-10 scale with an additional open space to write comments or improvement suggestions.

\section{Results}

We present the results observing the two evaluated blocks: process and product.

Regarding the process, an Independent samples Man-Whitney U test was conducted in order to compare Primary and Infant teacher students vs PET students. We analyzed the elements that integrate the four dimensions Planning, Organization, Development and Assessment.

As can be seen in Table 2, the majority of elements report that PET students perform significantly better than other education students in terms of self-management. Only one of the thirteen elements (Analysis of proposal) presents no significant differences between both groups.

Considering that significant differences are observed in nearly all elements, we proceeded to analyze differences between these items in terms of effect size. It seems very interesting to note that the elements which belong to the dimension Planning, present lower effect size than the other dimensions (average of $r=-0.43$ ); the three planning elements that present significant differences show a medium size. Contrasting with this fact, the elements that belong to the dimension Organization have an average of $r=-0.60$, that is to say all five elements present a large effect. In the other two dimensions (Development and Evaluation) we observe that both contain one element that presents a medium size and another which presents a large effect. If we analyze the elements separately, we observe that the elements that have an analytical nature (Monitoring [ $\mathrm{r}=-0.37]$ and Improvement_orientation [ $\mathrm{r}=-0.39]$ ) present the mentioned medium size and those which have an action nature (Actions [ $r=-0.58]$ and Assessment_criteria [ $r=-0.52]$ ) present a large effect.

\begin{tabular}{|c|c|c|c|c|c|c|c|}
\hline Dimensions & Elements / Criteria & $N$ & $\begin{array}{c}\% \\
P E T\end{array}$ & $\begin{array}{l}\text { Mann- } \\
\text { Whitney U }\end{array}$ & $\begin{array}{c}\text { Sig. } \\
\text { (2-tailed) }\end{array}$ & Z & $r$ \\
\hline \multirow{4}{*}{ Planning } & 1.1 Motivation & 58 & 19 & 101.5 & 0.002 & -3.11 & -0.41 \\
\hline & 1.2 Analysis_of_proposal & 58 & 19 & 250.0 & 0.866 & -0.17 & -0.02 \\
\hline & 1.3 Formulation of Objectives & 58 & 19 & 90.0 & 0.001 & -3.37 & -0.44 \\
\hline & 1.4 Tasks_planning & 58 & 19 & 90.0 & 0.001 & -3.37 & -0.44 \\
\hline \multirow{5}{*}{ Organization } & 2.1 Time_management & 58 & 19 & 60.0 & 0.000 & -3.97 & -0.52 \\
\hline & 2.2 Assignment of responsibilities & 58 & 19 & 48.0 & 0.000 & -4.21 & -0.55 \\
\hline & 2.3 Assumption of responsibilities & 58 & 19 & 4.0 & 0.000 & -5.09 & -0.67 \\
\hline & 2.4 Estimation of resources & 58 & 19 & 0.0 & 0.000 & -5.15 & -0.68 \\
\hline & $\begin{array}{l}2.5 \text { Location_selection_ } \\
\text { resources }\end{array}$ & 58 & 19 & 33.0 & 0.000 & -4.59 & -0.60 \\
\hline \multirow{2}{*}{ Development } & 3.1 Actions & 58 & 19 & 37.5 & 0.000 & -4.39 & -0.58 \\
\hline & 3.2 Monitoring & 58 & 19 & 118.0 & 0.005 & -2.81 & -0.37 \\
\hline \multirow{2}{*}{ Evaluation } & 4.1 Assessment_criteria & 58 & 19 & 60.0 & 0.000 & -3.97 & -0.52 \\
\hline & 4.2 Improvement_orientation & 58 & 19 & 109.0 & 0.003 & -2.99 & -0.39 \\
\hline
\end{tabular}

The product was assessed by observing the final «island» designed by each group. The scores presented by the groups are expressed in terms of mean values distributed by the three defined criteria: Organization, Variety of objects and Relevance. The validation process to assure the quality of the assessment process developed by the six experts consisted of the estimation of the agreement level between them; this agreement was estimated with a standard deviation in each criterion.

\begin{tabular}{lcccc}
$\begin{array}{l}\text { Table } 3 \\
\text { Descriptive statistics of the final project scores }\end{array}$ & $\begin{array}{c}\text { (Mean) } \\
\text { Organization }\end{array}$ & $\begin{array}{c}\text { (Mean) Variety } \\
\text { of objects }\end{array}$ & $\begin{array}{c}\text { (Mean) } \\
\text { Relevance }\end{array}$ & Total \\
\hline Inf.Pri & 7.34 & 7.22 & 7.20 & 7.26 \\
PET & 8.72 & 8.50 & 8.83 & 8.69 \\
Difference_Inf.Prim-PET & -1.39 & -1.28 & -1.63 & -1.43 \\
SD (expert evaluators) & 0.92 & 0.91 & 0.88 & 0.80 \\
\hline
\end{tabular}

As shown in table 3, the SD values were lower than 1.0; that means that experts reported with a high level of agreement. Both groups present scores higher than 7.0 on a 1-10 scale; therefore all groups performed very well (in Spanish academic terms).

Regarding the mean values, the differences between groups were higher than 1.25 both in general and by criteria. These results suggest that there are differences between the project performed by PET students and students who belong to the other educational disciplines.

\section{Conclusions}

After developing the whole experience and according to Gisbert, Cela-Ranilla \& Isus (2010) we can suggest that 3D learning environments can be a very useful tool for working with skills that will be required of the future teachers and specifically PETs. In fact, educational institutions could use this kind of environments into consideration for forming professionals whose performance is especially oriented to action tasks.

This research work can be an element for establishing a base for describing, exploring and analyzing the specific role of PET by using complex learning environments derived from technological advances.

In terms of the methodology, the ex-post facto method used and the sample composition represent a limitation that requires us to be cautious at getting conclusions; even more, these must be observed in a clearly descriptive sense. In this sense, a qualitative analysis could be applied in order to deepen and explore the causes of the observed differences. This could be a further research line to face.

Additionally, we can state that the 3D learning environment is a space in which education students display a high level of performance in the skill of self-management showing their competences in an integrated manner. The fact that this experience was a mandatory task for participants constituted a strength but also a limitation. The students' attitude was conditioned by the expected academic performance and the professor's beliefs. This leads us to reflect on the convenience of extending our analysis from a more qualitative perspective.

In a very descriptive manner, results show differences between PET and Infant/Primary teacher students when they have to enact the dimensions of the self-management skill. Several authors (HodgesKulinna, et al., 2010; Ward \& Ko. 2006) have highlighted the different role of PET with regard to other professors. These findings could reinforce the idea that PET develop characteristics that make them different from other teaching professionals (Browers, Tomic \& Boluijt, 2011; Barker \& Rossi. 2011).

In sum, the present research work offers objective and positive information about professionals who dedicate their efforts to PE, specifically in their formation process. This could be very valuable in order to give prestige to PE as discipline and PET as professional activity.

\section{Acknowledgements}

This research was supported by the national RDPlan of the Ministry of Science and Innovation of Spain. The general project was: SIMUL@: «Evaluation of a Simulation Technological Environments for the Learning of Transversal Competences at University» (grant number: EDU200801479). The research groupARGET (ref: 2014SGR1399) coordinated the project and the authors would like to extend their sincere thanks to the ARGET members.

\section{References}

Allen, P. D. \& Demchak, C. C. (2011). Applied virtual environments: Applications of virtual environments to government, military and business organizations. Journal of Virtual Worlds Research, 4(1).

Alrayes, A. \& Sutcliffe, A. (2011). «Students' attitudes in a virtual environment (Secondlife).» Journal of Virtual Worlds Research, 4(1).

ANECA. (2005). Título de grado en magisterio. Libro blanco. [Degree in teaching. White Paper.] Madrid:Agencia Nacional de Evaluación de la Calidad y Acreditación. Retrieved from http://www.aneca.es/ var/media/150404/libroblanco_jun05_magisterio1.pdf 
Aviram, A. \& Eshet-Alkalai, Y. (2006). «Towards a theory of digital literacy: Three scenarios for the next steps.» European Journal of Open, Distance and E-learning, 1.

Barker, D. \& Rossi, A. (2011) Understanding teachers: The potential and possibility of discourse analysis. Sport. Education and Society. 16(2). 139-158.

Brouwers, A. Tomic. A. \& Boluijt. H. (2011). Job demands. job control. social support and self-efficacy beliefs as determinants of burnout among physical education teachers. Europe's Journal of Psychology. 1. 17-39.

Burkhardt, G., Monsour, M., Valdez, G., Gunn, C., Dawson, M., Lemke, C., Coughlin, E., Thadani, V. \& Martin, C. (2003). enGauge 21stcentury skills: Literacy in the digital age. Naperville, IL: North Central Regional Educational Laboratory. Retrieved from http:// pict.sdsu.edu/engauge21st.pdf

Cela-Ranilla, J., Esteve, V., Marqués L., Gisbert, M., Arias, I., Vaca, B.E. \& Samaniego, GN. (2011). SIMUL@: 3D spaces to learn generic skills. A pilotstudy with Education students. In Proceedings of the 6th International Conference on e-Learning. University of British Columbia Okanagan, Kelowna; Canada. 27-28 June 2011.

Chang, Y. C., Peng. H. Y. \& Chao. H. C. (2010). Examining the effects of learning motivation and of course design in an instructional simulation game. Interactive Learning Environments. 18(4). 319339.

Ezziane, Z. (2007). Information Technology Literacy: Implications on Teaching and Learning. Educational Technology \& Society, 10 (3), 175-191.

Field, A. (2005): Discovering statistics using SPSS. Second edition. London: SAGE.

Fritz, C. O., Morris, P. E., \& Richler, J. J. (2012). Effect size estimates: current use, calculations, and interpretation. Journal of Experimental Psychology: General,141(1), 2.

Girvan, C., \& Savage, T. (2010). «Identifying an appropriate pedagogy for virtual worlds: A Communal Constructivism case study.» Computers and Education, 55(1), 342-349.

Gisbert. M., Cela-Ranilla. J. \& Isus, S. (2010). Las simulaciones en entornos TIC como herramienta para la formación en competencias transversales de los estudiantes universitarios. [Simulations in ICT environments as tool to develop transversal competences of university students]. Teoría de la Educación. Educación y Cultura en la Sociedad de la Información. 11. 352-370.

Green, S. B. \& Salkind, N. J. (2008). Using SPSS for Window and Macintosh: Analyzing and understanding data (5th ed.). Upper Saddle River, NJ: Pearson Prentice Hall.

Hendry, L. (1975). Survival in a Marginal Role: The Professional Identity of the Physical Education Teacher. The British Journal of Sociology. 26(4). 465-476.

Hind, E. \& Palmer, C. (2007). A critical evaluation of the roles and responsibilities of the Physical Education teacher-perspectives of a student training to teach P. E. in Primary Schools. Journal of Qualitative Research in Sports Studies, 1-9.

Hodges-Kulinna. P., Brusseau. T., Ferry. M. \& Cothran. D. (2010). Pre-service teachers' belief systems toward curricular outcomes for physical education. Research Quarterly for Exercise and
Sport 2010, 81(2):189-198.

Hoyle. E. (2001) Teaching: Prestige. Status and Esteem. Educational Management and Administration. 29(2). 139-152.

Kougioumtzis. K., Patriksson. G. \& Stråhlman, O. 2011. Physical education teachers' professionalization: A review of occupational power and professional control. European Physical Education Review. 17(1). 111-29.

Leech. N. L., \& Onwuegbuzie. A. J. (2002). A call for greater use of nonparametric statistics. Proceedings of the Annual Meeting of the Mid-South Educational Research Association, Chattanooga, Tennessee. Retrieved from http://www.eric.ed.gov/PDFS/ ED471346.pdf

Morillo. D., Santos. P. Pérez. D., Delgado. C., Ibáñez. M. B. and Hernández-Leo, D. (2010) Assessment in 3D virtual worlds: QTI in Wonderland. Congreso Iberoamericano [Congress of Educative Informatics. IE2010] Santiago de Chile. Chile. 1-3 Dec. 2010

O’Bryant, C.P., O’Sullivan, M., \& Raudensky, J. (2000). Socialization of prospective physical education teachers: The story of new blood. Sport, Education and Society, 5(2), 177-193

OECD. (2005). The definition and selection of key competencies (DeSeCo). Executive summary. Organization for Economic Cooperation and Development (OECD). Retrieved from http:// www.oecd.org/pisa/35070367.pdf

Partnership for 21st Century Skills. (2011). P21 common core toolkit. A guide to aligning the common core state standards with the framework for 21st century skills. Retrieved from http:// www.p21.org/storage/documents/P21CommonCoreToolkit.pdf

Prades, A. (2005). Les competències transversals i la formació universitària. [Generic skills and university education] Thesis, Universitat de Barcelona. Retrieved from http://www.tdx.cat/handle/ 10803/2346

Romero. C., Zagalaz. M.L., Romero Rodríguez. M.N. \& Martínez E.J. (2011). Importance of the professional competencies of the Primary Teachers in Physical Education expressed by the students. Retos. Nuevas tendencias en Educación Física. Deportey Recreación. 19. 62-68.

Samaniego, G., Vaca, B., Esteve, V., Cela, J., Marqués, M., Gisbert, M. \& Minelli, J. (2011). Configuración de objetos de aprendizaje en entornos virtuales $3 D$. VII International Conference on Information and Communication Technologies in Education I-Challenge 2011. Braga, Portugal.

Simpson, R. D. (2003). ASearch for the Complete Education: Balancing the Needs for Survival and Fulfillment. Innovative Higher Education, 28(2), 91-105.

Simul@(2012).SIMUL@: Evaluation of a Simulation Technological Environment for the Learning of Transversal Competences at University (Ref.: EDU2008-01479). Retrieved from http://atedpedago.urv.cat/simula

Tozer, S., \& Horsley, H. (2006). Professional development of teachers in physical education: Where are we now? Journal of Teaching in Physical Education, 25(4), 450-457.

Ward. P. \& Ko. B. (2006). Publication trends in the Journal of Teaching in Physical Education from 1981 to 2005. Journal of Teaching in Physical Education. 25(3). 266-280.

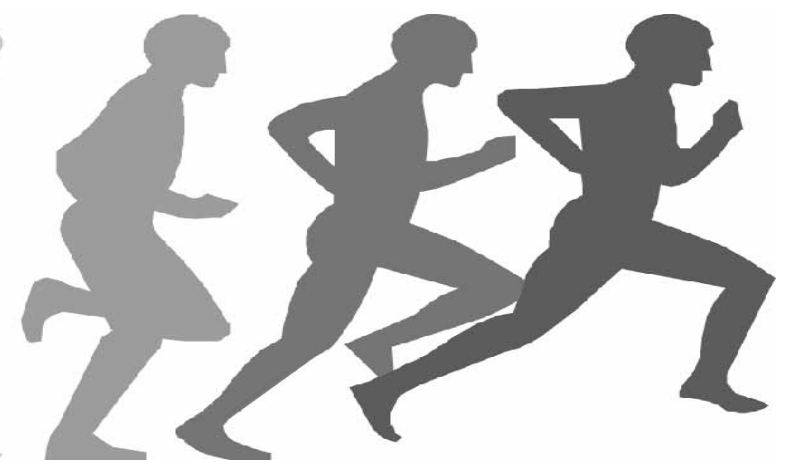

